\title{
Biosensors for Pesticides detection in Food
}

\author{
Carmen Moldovan ${ }^{1}$, Bogdan Firtat ${ }^{1}$, Silviu Dinulescu ${ }^{1}$, Costin Brasoveanu ${ }^{1}$, Marian Ion ${ }^{1}$, Mihaela \\ Savin ${ }^{1,}{ }^{3}$ Carmen Mihailescu ${ }^{2}$, Dana Stan ${ }^{2}$ \\ ${ }^{1}$ National Institute for R\&D in Microtechnologies, 126A, Erou lancu Nicolae, Voluntari, Romania \\ ${ }^{2}$ DDS Diagnostic, 1 Segovia, Bucharest, Romania \\ ${ }^{3}$ University of Bucharest, Faculty of Chemistry, Regina Elisabeta Blv, Bucharest, Romania \\ Corresponding author's e-mail address: carmen.moldovan@imt.ro
}

\begin{abstract}
The paper is presenting the work related to development of a fully integrated platform for pesticides detection based on amperometric Achetilcholinesteraze (AChE) enzyme biosensors, to be used in food monitoring giving quantitative information on the organophosphate and carbamate pesticides. The sensor design, fabrication, and characterisation and the platform components and functioning will be presented.
\end{abstract}

Key words: micro-biosensors, integrated platform, pesticide detection, food control.

\section{Introduction}

Pesticides used to indicate chemicals, synthetic or natural, that are used for the control of insects, fungi, bacteria, weeds, nematodes, rodent and other pests [1]. The pesticides residues may enter into the food chains through air, water and soil and causes several health problems to ecosystems, including human beings. In the food industry the detection of contaminants, verification of product content, monitoring of raw materials conversion and product freshness are more and more using miniaturised sensors. Enzymatic biosensors based on the selective inhibition of specific enzymes by different classes of toxic compounds are popular in the area of toxins detection. The decrease of activity of the immobilized enzyme in the presence of the analyte is used for its quantification [2].

\section{Sensors fabrication}

The miniaturized, planar, amperometric biosensor has been fabricated on silicon substrate using microtechnology techniques and Acethylcholinesterase (AChE) enzyme immobilization on the working electrode.

We work on $n<100>$ silicon wafers, and we continue by growing $500 \mathrm{~nm}$ thermal $\mathrm{SiO}_{2}$ and successively deposition and patterning of $\mathrm{Ti} / \mathrm{Pt}$, $\mathrm{Ti} / \mathrm{Au}$ and $\mathrm{Ti} / \mathrm{Ag}$ for three electrodes amperometric transducer fabrication (Fig.1);
Two working electrodes (WE) are patterned on the chip for possible differential measurements or just connecting them together for increasing the active sensitive area. The working electrode used to be functionalized with 3mercaptopropanoic acid (3-MPA) and 11mercaptoundecanoicacid (11-MUA), after that following: immersion in EDC/NHS molar report $1: 4,1 \mathrm{~h}$ for activation of the carboxyl group, cleaning in DI Water, 3 minutes and drying and enzyme deposition using a plotter or immersion for $4 \mathrm{~h}$ in enzymatic solution

\section{Testing and results}

The biosensors have been tested in presence of tomatoes and grapes with addition of Coumaphos in different concentration. The protocol for biosensor activation and reactions in presence of tomatoes or grapes sample in PBS (1:1) and organophosphate Coumaphos in concentration decreasing from $10^{-7} \mathrm{mM} / \mathrm{L} \div 10^{-4}$ $\mathrm{mM} / \mathrm{L}$ is presented in the Table 1 . The testing results are presented in Fig. 3 and 4.

Additionally, a fully functional automated platform (Fig.5) has been fabricated, able to accommodate different sensors, using a prefilled vessel with 12 mini-chambers, actuated by a step by step motor and to perform Computer control, Data storage, interpretation and alarming 


\section{Conclusions}

We obtained a silicon chip biosensor with AChE enzyme immobilised on WE, disposable and allowing the amperometric detection of organophosphate and carbamate pesticides up to the lower limit of $10^{-9} \mathrm{M} / \mathrm{l}$ based on inhibition of AChE in vegetables, fruits, and other fresh food products and an automated, mobile, low cost and automated platform to be used on field.

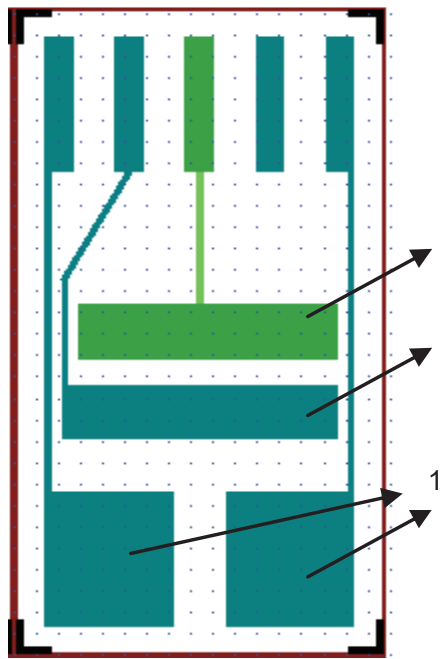

Fig. 1 - Amperometric transducer layout

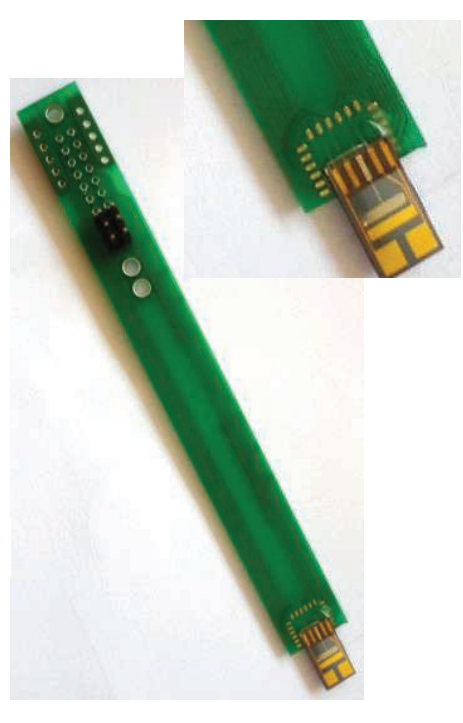

Fig. 2 - Fabricated device

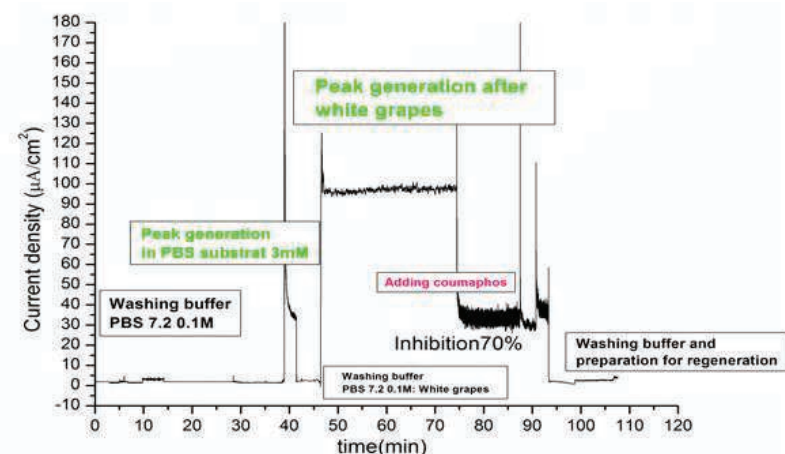

Fig. 3 - Testing results (tomato juice)

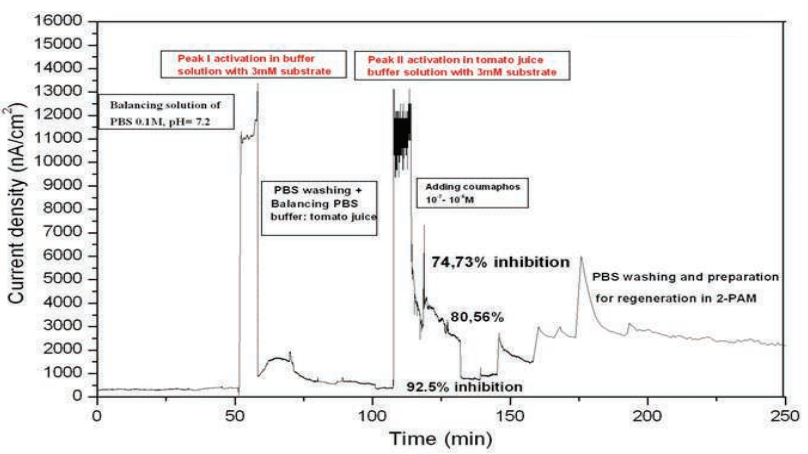

Fig. 4 - Testing results (grape juice)
Table 1 - Biosensor activation and reactions protocol

\begin{tabular}{|c|c|c|c|c|}
\hline STEP & Description & Reagent & $\begin{array}{l}\text { Incubation } \\
\text { time (min) }\end{array}$ & Signal \\
\hline 1. & Equilibration & $0.1 \mathrm{MPBS}, \mathrm{pH}=7.2$ & $\begin{array}{l}60 \text { min } \\
\text { Recording } \\
20 \text { min }\end{array}$ & $\begin{array}{l}\text { Current } \\
\text { density } \\
\text { function of } \\
\text { time }\end{array}$ \\
\hline 2. & $\begin{array}{l}\text { Peak } \\
\text { generation }\end{array}$ & ATCh 3mM & $10 \min$ & $-/ /-$ \\
\hline 3. & Washing & $0.1 \mathrm{MPBS}, \mathrm{pH}=7.2$ & $5 \mathrm{~min}$ & $-/ /-$ \\
\hline 4. & $\begin{array}{l}\text { Peak } \\
\text { generation }\end{array}$ & $0.1 \mathrm{MPBS}, \mathrm{pH}=7.2$ & $20 \min$ & $-1 /-$ \\
\hline 5 & Washing & $0.1 \mathrm{MPBS}, \mathrm{pH}=7.2$ & $5 \mathrm{~min}$ & $-/ /-$ \\
\hline 6. & Equilibration & $\begin{array}{l}\text { PBS: Tomatoes } \\
\text { juice }(1: 1) \text { or } \\
\text { PBS: Grapes } \\
\text { juice }(1: 1)\end{array}$ & $30 \min$ & $-/ /-$ \\
\hline 7. & $\begin{array}{l}\text { Peak } \\
\text { generation }\end{array}$ & ATCh 3mM & $15 \min$ & $-1 /-$ \\
\hline 8. & $\begin{array}{l}\text { Incubation with } \\
\text { Coumaphos }\end{array}$ & $\begin{array}{l}10^{-7} \mathrm{mM} / \mathrm{l} \\
10^{-6} \mathrm{mM} / \mathrm{ml} \\
10^{-4} \mathrm{~m} \mathrm{M} / \mathrm{ml}\end{array}$ & 15 min each & $-/ /-$ \\
\hline 9. & Regeneration & $\begin{array}{l}2- \\
\text { Pyridinealdoxime } \\
\text { methiodide } 99 \%\end{array}$ & $20 \min$ & $-/ /-$ \\
\hline
\end{tabular}

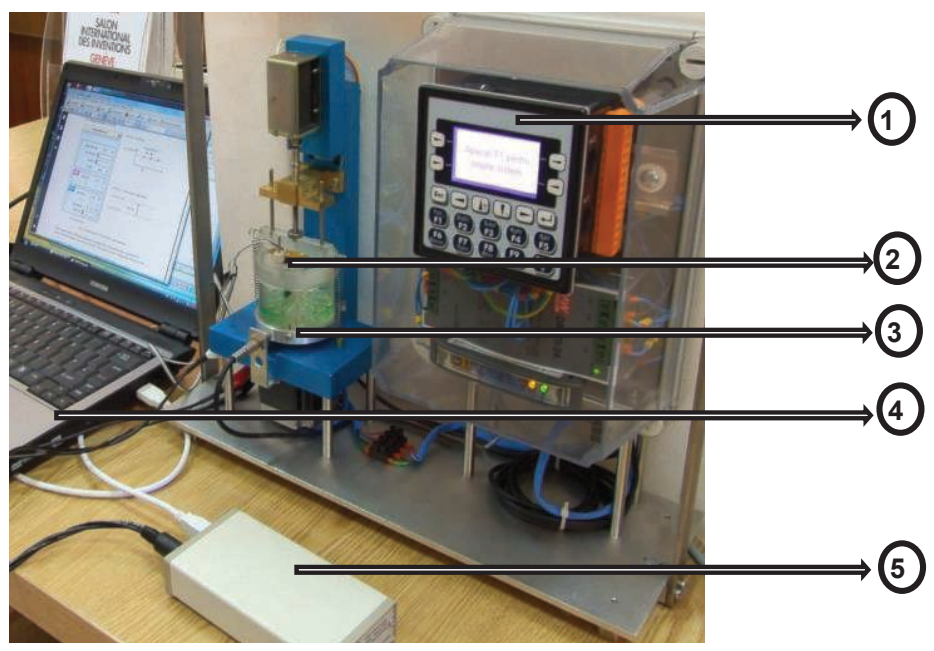

Fig. 5 - The automated platform

\section{References:}

[1] X. Jiang, DE. Li, X. Xua, Y. Ying., Y. Li, Z. Ye, J.Wang, Biosensors and Bioelectronics 23, 1577 (2008)

[2] N. Jaffrezic-Renault, S. Dzyadevych, Conductometric Microbiosensors for Environmental Monitoring, Sensors 2008, 8, 2569-2588 